\title{
TRADISI TUNGGUL WULUNG SEBAGAI SARANA PENGUAT JATI DIRI BANGSA
}

\author{
Lany Susanti ${ }^{1}$, Hermanu Joebagio ${ }^{2}$, Sri Yamtinah ${ }^{3}$ \\ ${ }^{1}$ Mahasiswa Magister Pendidikan Sejarah Universitas Sebelas Maret Surakarta \\ 2,3Dosen Program Studi Magister Pendidikan Sejarah Universitas Sebelas Maret Surakarta
}

\begin{abstract}
Abstrak
Jati diri bangsa merupakan identitas yang dimiliki oleh suatu bangsa yang menjadi ciri khusus. Jati diri bangsa akan terlihat dalam karakter bangsa yang merupakan perwujudan dari nilai-nilai luhur bangsa. Akan tetapi, akhir-akhir ini mulai di khawatirkan dengan melemahnya jati diri bangsa dalam masyarakat, salah satunya disebabkan dampak negatif berkembangnya ilmu pengetahuan dan teknologi yang menyebabkan degradasi moral. Masyarakat cenderung individualis karena segala sesuatu dapat dilakukan dengan mudah tanpa bantuan orang lain, yang akhirnya melunturkan nilai-nilai sosial, seperti kekeluargaan, gotong royong, dan toleransi. Kearifan lokal sebagai pusaka budaya memiliki peranan penting sebagai inspirasi dalam penguatan jati diri atau identitas bangsa. Penguatan jati diri suatu bangsa menjadipenting pada era globalisasi dengan tujuan agar tidak luntur akar budaya yang diwarisi daripara pendahulu ditengah-tengah homogenitas kebudayaan sebagai akibat globalisasi. Bangsa Indonesia mewarisi berbagai kekayaan alam, kekayaan hayati dan kekayaan keragaman sosiokultural. Kekayaan ini menjadi modal dasar yang harus di olah untuk kesejahteraan warga Indonesia. Kearifan lokal adalah modal budaya yang harus dikelola dan dikembangkan untuk memperkuat identitas ke-indonesiaan.Penelitian ini dilakukan melalui metode kualitatif yang dilakukan saat perayaan Tradisi Tunggul Wulung dengan observasi, wawancara, dan dokumentasi. Berdasarkan hasil penelitian yang dilakukan diperoleh hasil bahwa dalam Tradisi Tunggul Wulung banyak nilai-nilai sosial sebagai penguat jati diri bangsa, diantaranya adalah kekeluargaan, gotong royong, dan toleransi. Nilai-nilai tersebut terangkum dalam persiapan tradisi hingga pada saat perayaan Tradisi Tunggul Wulung.
\end{abstract}

Kata Kunci: Tradisi Tunggul Wulung, Sarana, Jati Diri Bangsa

\section{Pendahuluan}

Jati diri bangsa merupakan identitas yang dimiliki oleh suatu bangsa yang menjadi ciri khusus. Jati diri bangsa merupakan suatu kebanggaan bahkan menjadi daya tarik tersendiri yang harus tetap dijaga dan dilestarikan secara turun temurun pada generasi muda penerus bangsa. Jati diri bangsa akan terlihat dalam karakter bangsa yang merupakan perwujudan dari nilai-nilai luhur bangsa. Akan tetapi akhir-akhir ini kita mulai di khawatirkan dengan melemahnya jati diri bangsa dalam masyarakat salah satunya disebabkan oleh dampak negatif berkembangnya ilmu pengetahuan dan teknologi yang menyebabkan degradasi moral pada masyarakat.

Masyarakat cenderung individualis karena segala sesuatu dapat dilakukan dengan mudah dan tanpa bantuan orang lain yang pada akhirnya melunturkan nilainilai sosial yang selama ini berkembang dan berlaku di masyarakat seperti kekeluargaan, 
gotong royong, dan toleransi. Cipto dkk (2002) mengemukakan bahwa setidaknya terdapat delapan fenomena patologi sosial yang tersisa dari proses transisi yaitu hancurnya nilai demokrasi masyarakat, lunturnya kehidupan kewargaan dan nilai komunitas, kemerosotan nilai toleransi dalam masyarakat, memudarnya nilai kejujuran, kesopanan, dan rasa tolong menolong, melemahnya nilai dalam keluarga, praktek korupsi, kolusi, nepotisme penyelenggaraan pemerintahan, kerusakan sistem dan kehidupan ekonomi dan pelanggaran terhadap nilai kebangsaan.

Lahirnya identitas nasional atau jati diri bangsa tidak dapat lepas dari adanya dukungan faktor objektif yaitu faktor-faktor yang berhubungan dengan geografisekologis dan demografis, dan faktor subjektif yaitu faktor historis, politik, sosial dan kebudayaan yang dimiliki bangsa itu (Joko Suryo, 2002). Kearifan lokal sebagai pusaka budaya memiliki peranan penting sebagai inspirasi dalam penguatan jati diri atau identitas bangsa.

Penguatan jati diri suatu bangsa menjadi sangat penting pada era globalisasi dengan tujuan agar tidak luntur atau tercabutnya akar budaya yang diwarisi dari para pendahulu ditengah-tengah kecenderungan homogenitas kebudayaan sebagai akibat dari globalisasi. Bangsa Indonesia mewarisi berbagai kekayaan alam, kekayaan hayati dan kekayaan keragaman sosiokultural. Kekayaan ini merupakan modal dasar yang harus di olah untuk kesejahteraan warga indonesia. Kearifan lokal merupakan modal budaya yang harus dikelola dan dikembangkan yang nantinya akan memperkuat identitas keIndonesiaan.

Salah satu cara untuk dapat memperkuat jati diri bangsa bagi generasi muda adalah melalui pembelajaran formal di sekolah, penguatan jati diri bangsa sangat penting dilakukan guna menjaga generasi penerus bangsa ini tidak tergerus jiwa ke Indonesiaannya akibat dari perkembangan ilmu pengetahuan dan teknologi. Penanaman dan penguatan jati diri bangsa pada peserta didik harus dilakukan sejak mereka pada jenjang pendidikan formal karena guru ataupun orang tua dapat dengan mudah untuk memberikan pengawasan dan nasehat.

Selain pembelajaran formal di sekolah, jati diri bangsa dapat dikuatkan melalui interaksi dalam masyarakat ataupun melalui pelaksanaan kegiatankegiatan pada masyarakat yang sarat akan nilai-nilai luhur. Salah satunya adalah Perayaan Tradisi Tunggul Wulung yang dilakukan di Dusun Jurang Desa Pijiharjo Kecamatan Manyaran Kabupaten Wonogiri, yang sarat akan nilai-nilai luhur.

\section{Jati Diri Bangsa}

$$
\text { Djoko Santoso }
$$

mengungkapkan bahwa melemahnya semangat nasionalisme disebabkan oleh beberapa permasalahan diantaranya adalah 
kualitas sumber daya manusia yang rendah, militansi bangsa yang mendekati titik kritis dan jati diri bangsa yang sudah luntur identitas nasional atau jati diri bangsa.

Jati diri bangsa diartikan sebagai karakter bangsa sebagai watak yang merupakan identitas bangsa atau identitas nasional. Jati diri suatu bangsa berbeda dengan bangsa lain karena itu merupakan ciri khas. Hal tersebut dikarenakan oleh perbedaan latar belakang sejarah, kebudayaan, ataupun geografi. Jati diri bangsa Indonesia terbentuk karena rakyat Indonesia memiliki pengalaman sejarah yang sama. Pengalaman sejarah yang sama dpat menumbuhkan kesadaran kebangsaan yang kemudian pada akhirnya melahirkan identitas nasional atau jati diri bangsa (Chamim, 2003).

Menurut Tilaar (2007:32) jati diri bangsa merupakan sesuatu yang telah disepakati bersama seperti cita-cita masa depan yang sama berdasarkan pengalaman sejarah baik pengalaman yang mengembirakan maupun yang pahit. Dengan adanya tujuan yang sama membentuk ikatan bersama, rasa kekeluargaan, rasa saling memiliki, untuk mencapa tujuan atau masa depan yang lebih baik. Sejalan dengan pendapat Ki Hajar Dewantara yang mengatakan kebudayaan Indonesia merupakan puncak-puncak budaya dari masing-masing suku bangsa. Puncak-puncak kebudayaan dari suatu suku bangsa merupakan unsur-unsur budaya lokal yang dapat memperkuat solidaritas nasional. Didalam upaya tersebut peranan pendidikan nasional sangat efektif untuk mengembangkan kekayaan nasional dari masing-masing budaya lokal.

Selain dari jalur formal dalam membangkitkan identitas bangsa juga melalui informal pergaulan didalam masyarakat lokal sangat menentukan di dalam timbulnya ras penghargaan terhadap budaya sendiri serta sekaligus membina identitas bangsa Indonesia. Salah satunya adalah dengan menggali potensi daerah yaitu sejarah lokal. Sejarah lokal merupakan kekayaan yang memiliki banyak makna dan nilai yang bisa kita ambil didalamnya yang bisa digunakan sebagai pedoman hidup karena melalui nilai tersebut dapat membentuk jati diri dan karakter individu.

Nilai-nilai yang ada pada tradisi tersebut dapat membentuk perilaku, sikap dan karakter. Menurut Budiono Kusumohamijo (1993:32) nilai merupakan sesuatu yang dianggap positif dan dihargai, dipelihara, diagungkan, dihormati, membuat otrang gembira, puas dan bersyukur.

Sedangkan menurut Mukti (2003: 177), nilai adalah suatu konsep abstrak yang mendasar mengenai standar sikap dan perbuatan yang dapat menentukan jati diri individu, bagaimana individu tersebut hidup dan memperlakukan orang lain. Tingkah laku maupun karakter individu merupakan cerminan dari nilai yang dijadikan pedoman hidup. Jati diri bangsa merupakan identitas 
suatu bangsa yang menjadi kekayaan kebanggaan tersendiri. Jati diri bangsa akan terlihat dalam karakter bangsa yang merupakan perwujudan dari nilai-nilai luhur bangsa. Kearifan lokal sebagai pusaka budaya memiliki peranan penting sebagai inspirasi dalam penguatan jati diri atau identitas kltural atau bangsa. Penguatan jati diri suatu kelompok etnik atau bangsa menjadi sangat penting pada era globalisasi dengan tujuan agar tidak luntur atau tercabutnya akar budaya yang diwarisi dari para pendahulu ditengah-tengah kecenderungan homogenitas kebudayaan sebagai akibat dari globalisasi.

Bangsa Indonesia mewarisi berbagai kekayaan alam, kekayaan hayati dan kekayaan keragaman sosiokultural. Kekayaan ini merupakan modal dasar yang harus dioleh untuk kesejahteraan warga Indonesia. Kearifan lokal merupakan modal budaya yang harus dikelola dan dikembangkan yang nantinya akan memperkuat identitas keindonesiaan.

\section{Tradisi Tunggul Wulung}

Tunggul Wulung merupakan salah satu peninggalan sejarah yang hingga saat ini masih terus dirawat dan dilestarikan tradisinya oleh masyarakat Dusun Jurang Desa Pijiharjo Kecamatan Manyaran Kabupaten Wonogiri. Tunggul Wulung pada dasarnya adalah peninggalan berbentuk keris dan tongkat, menurut juru kunci benda tersebut merupakan peninggalan dari pelarian Majapahit. Menurut cerita bahwa semasa menjelang runtuhnya Kerajaan Majapahit sebagaian tokoh dan pengikutnya melarikan diri karena adanya serangan Demak. Alasan mereka melarikan diri karena menolak kedatangan Islam.

Sejalan dengan yang diungkapkan oleh Djafar dalam Putranto (2003) bahwa pada saat Kerajaan Majapahit berada pada ambang keruntuhan dengan salah satu faktor penyebabnya adalah mulai masuknya pengaruh agama Islam di Jawa, para tokoh kerajaan meninggalkan istana untuk melarikan diri atau mengasingkan diri karena menolak kedatangan agama Islam.

Diantara para tokoh kerajaan Majapahit termasuk juga dikisahkan bahwa Prabu Brawijaya yang merupakan raja terakhir Majapahit yang melarikan diri ke Wilayah Gunung Kidul beresama para pengikut setianya (Putranto, 2003: 225). Jika dilihat berdasarkan letak geografis dusun Jurang merupakan daerah yang berbatasan langsung dengan wilayah Gunung Kidul. Selain itu letak dusun Jurang berada di atas bukit yang merupakan tempat berpotensi untuk tempat melarikan diri atau bersembunyi pada masa itu.

Meskipun Dusun Jurang terletak diatas bukit akan tetapi Jurang merupakan salah satu dusun yang terkenal hasil panennya berlimpah karena tanahnya yang subur untuk lahan pertanian selain itu masyarakat Jurang terkenal rajin dan ulet dalam bekerja mereka dapat mengolah lahan pertanian secara maksimal. Sehingga, 
hasil penen dari Jurang terkenal bagus dan bermutu dibandingkan daerah lain. Keberadaan Tunggul Wulung sebagai salah satu bukti dan peninggalan pelarian Majapahit seperti yang diungkapkan oleh juru kunci dan sesepuh dusun Jurang dapat diakui kebenarannya.

Hal tersebut didukung oleh hasil penelitian yang dilakukan oleh Putranto (2003) dijelaskan bahwa tokoh bernama Betara Katong yang prnah tinggal di dusun Betoro Kidul dan Desa Karang Asem, Kecamatan Ponjong yang sebenarnya memiliki nama Jaka Umbaran berasal dari Majapahit tepatnya keturunan Prabu Brawijaya yang mengganti namanya menjadi Betara Katong dengan tujuan untuk menghilangkan identitas aslinya agar tidak diketahui oleh tentara Islam yang megejarnya.

Betara Katong yang tinggal di dusun Betoro pada awalnya menetap di Kadipaten Gondang (Tegal) dan selang 15 tahun kemudian beliau pindah ke Tegal Betoro yang kemudian dikisahkan Betoro Katong moksa. Keturunan Betoro Katong bernama Mbah Bodo yang tinggal dan memiliki keturunan di Betoro akan tetapi pada suatu hari datang mbah Sakrip dari Bayat, Klaten yang beragama Islam ke Betoro yang menyebabkan para pengikut Mbah Bodo memeluk agama Islam.

Sementara itu, Mbah Bodo tetap memeluk agama yang dianut oleh Betoro Katong (kemungkinan besar Hindu) dan memilih pindah ke daerah Dongang Wonogiri dan pindah lagi ke daerah Manyaran. Sedangkan pengikut Mbah Bodo yang telah masuk Islam menikah dengan pengikut Mbah Sakrip dan menghasilkan keturunan yang menjadi cikal bakal Dusun Betoro Kidul.

Tradisi Tunggul Wulung yang berada di dusun Jurang Kecamatan Manyaran Kabupaten Wonogiri merupakan tradisi yang dilakukan secara turun temurun yang merupakan ungkapan rasa syukur kepada Sang Pencipta atas berkah kesehatan dan rejeki, salah satunya adalah ucapan syukur atas berkah panen berlimpah. Berdasarkan hasil observasi dan wawancara yang dilakukan diperoleh beberapa informasi diantaranya adalah masyarakat Dusun Jurang menganggap bahwa Tunggul Wulung merupakan pelindung dan pembawa berkah bagi masyarakat dusun Jurang, maka dalam satu tahun sekali di dusun Jurang dilakukan Tradisi Kirab Tunggul Wulung mengelilinggi dusun Jurang sebagai ungkapan rasa syukur.

Perayaan tersebut dilakukan pada penanggalan Jawa bulan Besar pada hari kamis kliwon, jika pada Bulan Besar tidak ada hari kamis kliwon maka Tradisi Kirab Tunggul Wulung dilakukan pada hari kliwon terakhir pada bulan Besar. Persiapan tradisi Tunggul Wulung sendiri dilakukan beberapa hari sebelumnya dengan melakukan rapat bersama masyarakat Dusun Jurang agar pelaksanaan Tradisi Tunggul Wulung dapat 
berjalan dengan baik. Selain itu dengan adanya musyawarah sebelumnya bertujuan untuk pembagian tugas dan tanggung jawab yang harus dilakukan oleh masyarakat dusun Jurang.Persiapan Perayaan Tradisi Tunggul Wulung dilakukan sehari sebelumnya sudah dilakukan seperti bersihbersih dusun, semua warga turun ke jalan untuk bersih-bersih dusun.

Selain itu sehari sebelumnya jika ada warga yang mengirim hewan sebagai ungkapan rasa syukur seperti sapi dan kambing maka penyembelihan hewan tersebut dilakukan sehari sebelumnya di rumah juru kunci. Setelah itu daging hewan tersebut dibagikan kepada masyarakat Dusun Jurang selain itu sebagaian di masak untuk acara pada malam tirakatan untuk makan bersama warga. Pada malam hari warga berkumpul di rumah juru kunci untuk tirakatan dan melihat pusaka Teken dan Keris Tunggul Wulung yang hanya dikeluarkan satu tahun sekali pada perayaan Tradisi Kirab Tunggul Wulung.

Sebagian warga yang wanita telah membantu persiapan malam tirakatan dari masak untuk makan bersama warga juga untuk persiapan sesajen seperti ingkung, jenang dan tumpeng. Pada pukul 10 malam semua tumpeng, ingkung, dan sesaji dikeluarkan untuk di ijabkan oleh modin dusun. Setelah itu warga makan bersama dan nasi tumpeng serta ingkung dibagikan kepada warga. Setelah acara makan bersama selesai sebagian warga kembali ke rumah dan sebagian warga masih ada yang tinggal di rumah juru kunci untuk tirakatan tidak tidur semalam suntuk sampai pagi untuk menjemput berkah dari tunggul wulung.

Pada pukul 02.00 WIB ibu-ibu warga Dusun jurang menuju kerumah juru kunci untuk mengantar nasi ketan yang sudah di masak dirumah warga masing-masing yang dalam proses memasaknya tidak boleh di icipi, menurut kepercayaan warga itu tidak baik karena itu merupakan sesaji. Setiap ibu-bu yang mengantar nasi ketan akan diberikan 1 buah oleh-oleh yang berisi tembakau, daun sirih, dan kapur sirih yang harus dibawa pulang oleh masyarakat.

Setelah nasi ketan terkumpul yang berjumlah lebih dari 100 giling nasi ketan ditata diatas meja. Pada saat azan subuh juru kunci bersiap untuk melakukan kirab tapi terlebih dahulu juru kunci berdandan menggunakan pakaian jawa layaknya pengantin laki-laki jawa, pada saat kirab dilakukan diikuti oleh beberapa laki-laki sebagai pengawal juru kunci. Kirab dilakukan mengelilingi Dusun Jurang menuju wono leren.

Wono leren adalah hutan kecil yang berada ditengah-tengah sawah yang merupakan dulunya adalah tempat beristirahatnya Simbah Tunggul Wulung ketika dalam perjalanan menuju dusun Jurang. Sebelum juru kunci dan rombongan sampai pada wono leren sebagaian warga laki-laki sudah sampai terlebih dahulu 
untuk membersihkan wono leren, setelah juru kunci dan rombongan datang maka juru kunci akan menaruh pusaka teken dan keris tunggul wulung pada pohon yang beradaq di tengah wono leren yang selanjutnya dilakukan doa oleh juru kunci dengan menggunakan bahasa Jawa.

Ketika acara di wono leren selesai selanjutnya juru kunci membawa kembali pusaka Tunggul Wulung untuk melakukan kirab mengelilingi Dusun diikuti para pengawal dan warga laki-laki. Menuju pada Sasana Tunggul Wulung yang di Sasana tersebut telah berkumpul semua warga lakilaki, perempuan, dan anak-anak yang bersih-bersih sasana tersebut. Sasana adalah sebuah rumah yang dulunya merupakan tempat menaruh Pusaka Tunggul Wulung atau tempet duduk Tunggul Wulung. Sasana tersebut hanya boleh dibersihkan setahun sekali pada saat Kirab Tunggul Wulung.

Sesampainya di Sasana Pusaka dibawa mengelilingi Sasana sebanyak tiga kali sembari berdoa dan menaburkan bunga. Salah satu pengawal membawa bedak yang terbuat dari kunyit dan tepung beras yang dibuat dari subuh yang kemudian masing-masing warga meminta bedak untuk dioleskan ke badan mereka, semua warga wajib mengambil bedak tersebut bahkan jika ada warga yang tidak bisa datang mengikuti kirab ataupun bersihbersih di Sasana harus tetap di ambilkan oleh anggota keluarga yang lain. Menurut kepercayaan warga bedak tersebut membawa berkah dan kesehatan bagi warga dusun Jurang. Di dalam Sasana tersebut tersebut terdapat tempat air yang hartus diisi selama sepasar sekali pada pasaran kliwon pada sore hari menjelang mahgrib oleh juru kunci.

Pada hari-hari biasa wanita tidak diperbolehkan mengunjungi Sasana Tunggul Wulung tersebut yang diperbolehkan hanya Juru Kunci dan warga laki-laki. Menurut hasil wawancara yang dilakukan dengan juru kunci diperoleh informasi bahwa air yang berada di sasana tersebut dipergunakan warga untuk obat jika ada warga yang sakit dan dipercaya dapat menyembuhkan sakit tersebut. Pengambilan air tersebut harus dilakukan oleh Juru Kunci, warga biasa tidak diperkenankan mengambil air sendiri.

Air yang di tuangkan oleh juru kunci pada adah air di Sasana tersebut diambil dari sumber air yang berada di bukit dusun Jurang. Setelah selesai prosesi di Sasana Tunggul Wulung selanjutnya pusaka dibawa kembali ke tempat juru kunci untuk selanjutnya pusaka tersebut akan dibasuh dengan air kembang. Air kembang tersebut di buat oleh Ibu Sumiyem yang telah puluhan tahun membuat air kembang tersebut. Air kembang terbuat dari rendaman air bunga kanthil, kenanga, melati dan mawar. Pada waktu ini pusaka dibuka dari bungkusnya kemudian di basuh dengan air kembang sebagai wujud hormat 
dan memberikan bau harum pada pusaka tersebut. Dalam upacara ini juru kunci membacakan doa dengan bahasa Jawa yang tidak diketahui oleh warga. Setelah itu, Pusaka Tunggul Wulung kembali dimasukkan ke tempatnya. Warga yang telah berkumpul di rumah juru kunci mengeluarkan semua nasi ketan yang telah dihantarkan pada malam hari sebelumnya, dilakukan do'a bersama sebagai ungkapan rasa syukur terhadap berkah yang melimpah kepada masyarakat Dusun Jurang.

Nasi ketan tersebut di bagikan dan dibawa pulang oleh warga tanpa ada yang tersisa, karena menurut kepercayaan warga memakan, mengambil dan membawa sesajen ataupun makanan yang ada pada acara tradisi Tunggul Wulung akan membawa berkah dan rejeki bagi mereka. Kirab pusaka di Dusun Jurang, Desa Pijiharjo, kecamatan Manyaran sebagai salah satu penerusan tradisi leluhur.

Tujuan sesungguhnya dari kirab adalah penghormatan manusia kepada Tuhan Yang Maha Esa dan alam yang telah ramah dan memberikan kesejahteraan kepada warga dusun Jurang dan sekitarnya. Oleh karena pusaka Tunggul Wulung pada dasarnya adalah sebagai lambang kesuburan dusun Jurang. Di dalam persiapan dan pelaksanaan tradisi kirab tungggul wulung seluruh masyarakat berperan serta secara bersama-sama bergotong royong mempersiapkan ubo rampe (sesaji), membersihkan dusun, membersihkan tempat atau sasono, serta mengikuti kirab tersebut dari anak-anak sampai dengan para sesepuh. Mereka bersama-sama mengikuti prosesi dan berdoa bersama meskipun didusun jurang sendiri memeluk agama yang berbeda-beda dan sebagian lagi masyarakat disana juga ada yang pendatang.

\section{Nilai-Nilai Pada Tradisi Tunggul Wulung}

Pada Tradisi Tunggul Wulung terdapat nilai-nilai luhur yang dapat kita ambil, diantaranya:

\section{Gotong Royong}

Masyarakat Indonesia terkenal dengan kerjasama dan saling membantu, dan hal tersebut sudah mulai pudar di masyarakat. Gotong Royong dalam Tradisi Tunggul Wulung dapat dilihat dari kebersamaan masyarakat dalam mempersiapkan perayaan kirab tradisi Tunggul Wulung. Laki-laki, perempuan, anak-anak, tua dan muda saling bekerjasama dan gotong royong untuk membuat persiapan.

2. Kekeluargaan

Kekeluargaan merupakan cerminan dari kesatuan, seperti Indonesia yang terdiri dari banyak suku, budaya, dan bahasa yang melebur satu kesatuan, yaitu Indonesia menjadi satu rumah satu keluarga.

3. Toleransi

Indonesia merupakan negara multikultural salah satunya adalah perbedaan ras, suku, budaya bahkan agama 
yang dapat hidup menjadi satu keluarga dan berdampingan dengan baik, hal tersebut adanya toleransi yang tinggi antar masyarakat. Sama hal nya pada Kirab Tradisi Tunggul Wulung bahwa didalam pelaksanaan kegiatan tersebut dari beberapa agama mengikuti kegiatan tersebut tanpa membeda-bedakan.

4. Kepatuhan/Ketaatan

Tradisi Tunggul Wulung merupakan tradisi yang secara turun temurun dilestarikan dan tetap dilakukan sampai saat ini oleh generasi masyarakat dusun Jurang itu merupakan sikap patuh dan ketaatan pada Tradisi dan Budaya yang ada pada di dusun Jurang walaupun era saat ini sudah sangat modern tetapi generasi muda tetap mau mau menjaga tradisi tersebut.

\section{Hormat}

Salah satu sikap yang muncul pada Tradisi Tunggul Wulung adalah rasa hormat masyarakat pada sesepuh di dusun Jurang.

6. Musyawarah

Masyarakat Dusun Jurang dalam persiapan tradisi tunggul wulung terlebih dahulu melakukan musyawarah bersama untuk membagi kerja dan tanggung jawab dari masyarakat agar tidak ada kesalahan.

\section{Penutup}

\section{Kesimpulan}

Jati diri bangsa merupakan identitas suatu bangsa yang menjadi kekayaan kebanggaan tersendiri. Jati diri bangsa akan terlihat dalam karakter bangsa yang merupakan perwujudan dari nilai-nilai luhur bangsa. Kearifan lokal sebagai pusaka budaya memiliki peranan penting sebagai inspirasi dalam penguatan jati diri atau identitas kultural atau bangsa.

Penguatan jati diri suatu kelompok etnik atau bangsa menjadi sangat penting pada era globalisasi dengan tujuan agar tidak luntur atau tercabutnya akar budaya yang diwarisi dari para pendahulu ditengahtengah kecenderungan homogenitas kebudayaan sebagai akibat dari globalisasi. Bangsa Indonesia mewarisi berbagai kekayaan alam, kekayaan hayati dan kekayaan keragaman sosio-kultural.

Kekayaan ini merupakan modal dasar yang harus di oleh untuk kesejahteraan warga Indonesia. Kearifan lokal merupakan modal budaya yang harus dikelola dan dikembangkan yang nantinya akan memperkuat identitas ke-Indonesiaan.

\section{Daftar Pustaka}

Djoko Santoso. 2008. Ketahanan Negara dan Wawasan Kebangsaan Menghadapi Tantangan Global. Makalah disampaikan pada Simposium Nasional Peringatan Satu Abad Kebangkitan Nasional, 19 Mei 2008. Yogyakarta: UG, Pemda DIY, Kagama.

H.A.R. Tilaar. 2007. Mengindonesia: etnisitas dan identitas bangsa Indonesia. Jakarta: Rineka cipta.

Mukti, Krisnanda Wijaya. 2003. Wacana Buddha Dhamma. Jakarta: Yayasan Dharma Pembangunan.

Putranto, Andi. 2003. Pandangan Masyarakat Gunung Kidul Terhadap Pelarian Majapahit sebagai Leluhurnya (Kajian Atas Data Arkeologi dan Antropologi).Jurnal 
58 IJURNAL AGASTYA VOL 08 NO 01 JANUARI 2018

Humaniora UGM, Volume XV Nomor 2 Tahun 2003.

Joko Suryo. 2002. Pembentukan Identitas Nasional. Makalah disampaikan pada Seminar Terbatas Pengembangan Wawasan tentang CIVIC Education. Yogyakarta: LP3 UMY. 